\title{
EFFECT OF SALT LOADING ON METABOLIC CHANGES IN OVARIECTOMIZED RATS
}

\author{
By
Howida A. Saleh*, Dalia A. Saad*, Doaa A. Abou-Bakr*, Lobna El- Khateb** and Mona A. Ahmed* $^{*}$ \\ Departments of Medical Physiology* and Histology**, Faculty of Medicine, Ain Shams \\ University, Egypt \\ Corresponding author: Howida Ahmed Saleh Khashab \\ E-mail: howidaahmed@med.asu.edu.eg, Phone number: 01094988355
}

\begin{abstract}
Background: Menopause, a natural step in woman`s life aging process, is associated with increased risk of metabolic diseases. Salt, is an essential micronutrient, commonly added to food. However, studies addressing the metabolic effects of high salt intake are controversial and limited.
\end{abstract}

Objective: The present study was designed to determine the changes imposed by increased salt consumption on glucose and lipid homeostasis in ovariectomized rats that mimics the estrogen-deprived condition in postmenopausal women.

Material and Methods: Thirty six adult female albino Wister rats were allocated into 3 equal groups: Control group, ovariectomized group, and high salt ovariectomized group which received high salt $(2 \% \mathrm{NaCl})$ solution for 2 months. Rats were subjected to estimation of body weight (BW), body mass index (BMI), waist circumference (WC), and visceral fat weight. Glucose uptake by diaphragm and glucose output by kidneys were determined. Also, levels of glucose, lipid profile, malondialdehyde, catalase, insulin, estradiol and tumor necrosis factor- $\alpha$ were measured. Pancreatic and hepatic tissues were examined histopathologically. Also, caspase-3 was assessed in pancreas by immunohistochemistry.

Results: High salt ovariectomized group showed significant decrease in final WC, and significant increase in serum insulin, HOMA-IR, serum levels of MDA and TNF- $\alpha$ compared to the ovariectomized group. There were significant increases in plasma levels of glucose, triglycerides, total cholesterol, LDL-C, catalase, and AI, and significant decrease in glucose uptake by diaphragm, and plasma HDL-C in high salt group compared to control group.

As compared to ovariectomized group, the pancreas in salt loaded group showed decreased number of islets of Langerhans and fatty degeneration together with increased caspase-3. Liver histology was also worsened, and hepatocytes showed ballooning, steatosis and inflammatory infiltration together with massive amounts of collagen fibers around portal tract.

Conclusion: High salt intake exacerbated the hyperglycemia and insulin resistance, intensified pancreatic apoptosis and hepatic fatty, and degenerative changes. These effects could be explained by salt loadinginduced exacerbation and exaggeration of oxidative and inflammatory influences of ovariectomy.

Key Words: Ovariectomy, menopause, estradiol, salt loading, oxidative stress, inflammation, hyperglycemia, hyperlipidemia, metabolic derangement. 


\section{HOWIDA A. SALEH et al.,}

\section{INTRODUCTION}

Menopause, the biological stage in a woman's life, is characterized by permanent cessation of menstruation and fertility secondary to the loss of ovarian function and estrogen deprivation (Dalal and Agarwal, 2015). It is associated with increased risk of metabolic diseases such as type 2 diabetes and metabolic syndrome and related co-morbidities, including obesity, insulin resistance, dyslipidemia and nonalcoholic fatty liver disease (NAFLD) (Chung et al., 2015).

With age advancing, women in the age of 35-55 years were more prone to diabetes and cardiovascular diseases in comparison to men (Logue et al., 2011). Moreover, postmenopausal females had high risk for development of diabetes, decline in whole body insulin-mediated glucose uptake, altered insulin level (Gibb et al., 2019), and increase production of ROS subsequent to estrogen deficiency (Ahmed et al., 2014).

After ovariectomy, not only glucose metabolism was disturbed, but also lipid profile with increase in serum total cholesterol, triglycerides, LDL-cholesterol (LDL-C), and decreased HDL-cholesterol (HDL-C) (Shady et al., 2015).

Salt, an essential micronutrient is commonly added to food to enhance taste, preserve food, and improve the appearance of processed foods. High salt intake is associated with increased risk for hypertension and cardiovascular mortality, which caused many professional societies to recommend limiting salt intake (Cogswell et al., 2016). Intake of a high salt diet was found to be associated with increased frequencies of obesity, insulin resistance, NAFLD and metabolic syndrome (Lanaspa et al., 2018). Experiments in humans placed on high salt diet showed reduced insulin sensitivity after 5 days (Takagi et al., 2018). Also, rats on a high salt intake were found to develop obesity with increased adipocyte size and leptin expression (Brey et al., 2019).

Could high salt intake be a factor implicated in the occurrence or worsening of the metabolic disturbances that associate menopause is questionable since to our knowledge it has not been addressed in previous researches. This was the aim of the present work.

\section{PATIENTS AND METHODS}

The present study was carried out on 36 adult female albino rats initially weighing 200-260 g. Rats were purchased from animal farm in Giza, and maintained in MASRI under standard conditions of boarding and feeding. Rats were housed in plastic cages (50X30X20-5 rats / cage) at room temperature, with normal light/dark cycles. Regular meals were introduced daily consisting of milk, bread and vegetables. Rats were left for 7 days as a period of acclimation prior to the experimental procedure. The present study was approved by the Research Ethics Committee 000017585, Faculty of Medicine, Ain Shams University.

\section{Experimental protocol:}

Rats included in the present study were allocated randomly into three equal groups:

\section{Group I: Sham-operated Control} (SHAM) group: Rats in this group were subjected to all surgical procedures of bilateral ovariectomy operation, except for 
removal of the ovaries. Rats were then immediately allowed ad libitum access to tap water.

\section{Group II: Ovariectomized (OVX)} group: Rats in this group were subjected to bilateral ovariectomy operation as described by Ingie and Griffith (1949). Rats were then immediately allowed ad libitum access to tap water following the operation.

Group III: High salt ovariectomized (HS-OVX) group: Rats in this group were subjected to bilateral ovariectomy operation. Rats were allowed ad libitum access to $2 \% \mathrm{NaCl}$ as drinking water according to Ahmed and Abd El Samad (2013).

Experimental procedures: At the end of the experimental period (8 weeks), overnight fasted rats were weighed and anesthetized by intraperitoneal injection of Thiopental sodium (EIPICO, Egypt), in a dose of $40 \mathrm{mg} / \mathrm{Kg}$. B.W. Rats were subjected to determination of body length to calculate BMI. Waist circumference was determined.

\section{Blood samples were collected:}

a. Plasma was used for immediate determination of glucose using kits supplied by Spectrum Diagnostics (Hannover, Germany). Plasma was also used for determination of catalase and lipid profile using kits supplied by Biodiagnostic, Egypt. Calculation of Plasma LDL-C was done according to Friedewald et al. (1972) using the following equation:

LDL-C $=$ Total cholesterol $-($ HDL-C + TG / 5)
Calculation of atherogenic index was done according to Grundy et al. (1987) as follows:

Atherogenic index $=$ Total
cholesterol $/$ HDL-C

b. Serum was stored at $-80^{\circ} \mathrm{C}$, and used for determination of malondialdehyde using kits supplied by Bio-diagnostic, Egypt. Eliza technique was used to determine serum TNF- $\alpha$ using kits supplied by Eiaab Wuhan Company, China, and to determine serum insulin and estradiol levels using kits supplied by My BioSource, San Diego, USA and Cussbio ${ }^{\circledR}$ Wuhan, Hubei, China respectively.

Homeostatic Model Assessment of Insulin Resistance (HOMA-IR) was calculated according to Matthews et al. (1985), using the following equation:

\section{HOMA-IR = Fasting insulin $x$ Fasting glucose/ 405}

All assays were performed according to the manufacturer's instruction.

2. Determination of glucose uptake by diaphragm and glucose output by both kidneys: Immediately after collecting the blood samples, diaphragm was carefully excised and used for the in vitro determination of glucose uptake according to the method described by Mohamed et al. (1975). Both kidneys were dissected out and used for determination of glucose output according to method described by Randall (1972), with modifications of ElNasr et al. (2011).

Visceral fat was collected, dried with filter paper, and then weighed. Pancreas and liver were fixed in paraffin and used for histological examination using 


\section{HOWIDA A. SALEH et al.,}

Hematoxylin and eosin stain (H\&E) (Bancroft and Gamble, 2002). Modified Masson's Trichrome Technique was used for assessment of fibrosis in liver according to Drury and Wallington (1976).

3. Immuno-histochemical studies of apoptotic marker caspase- 3 in pancreatic acinar cells were done using Modified Avidin-Biotin immune-peroxidase technique. The number of positive Caspase-3 immuno-stained cells was calculated per high power field (objective lens $\times 40$ ). Five fields of three serial sections of each rat from each group were examined using the image analyzer (CX 41RF, Olympus cooperation, Tokyo, Japan) at the Pathology Department, Faculty of Medicine, Al-Azhar University.
Images were digitized and captured with a CCD camera connected to a personal computer.

\section{Statistical analysis:}

All results were expressed as mean \pm SEM. One -Way ANOVA (Analysis of Variance) was used to test difference among the studied groups followed by LSD (least significant difference) to find intergroupal difference. Mann Whitney Test (U test) was used to assess the statistical significance of the difference of a non-parametric variable between the study groups. Statistical significance was performed by using Statistical Package for the Social Sciences (SPSS, Inc., Chicago, IL, USA) program, version 25.0. $\mathrm{P}$ value $\leq 0.05$ was considered significant.

\section{RESULTS}

Changes in body weight (BW), body mass index (BMI), visceral fat weight (VFwt), waist circumference (WC) and visceral fat to body weight ratio (VFW/ BW):

As shown in table (1), in ovariectomized group, final BW and final BMI significantly increased compared to the control group. Upon high salt administration, both parameters were nonsignificantly changed compared to ovariectomized group, but still significantly high compared to control group.

In ovariectomized group, final WC showed significant increase as compared to control group. In high salt ovariectomized group, final WC significantly decreased as compared to ovariectomized group but nonsignificantly increased as compared to the control group. Insignificant changes were observed in VFW and VFW/FBW in all studied groups. 
Table (1): Mean \pm SEM of body weight (BW), body mass index (BMI), visceral fat weight (VFwt), waist circumference (WC) and visceral fat to body weight ratio $(\mathrm{VFW} / \mathrm{BW})$ in all studied groups

\begin{tabular}{|c|c|c|c|}
\hline $\begin{array}{l}\text { Groups } \\
\text { Parameters }\end{array}$ & $\begin{array}{c}\text { SHAM } \\
\text { (12) }\end{array}$ & $\begin{array}{c}\text { OVX } \\
(12)\end{array}$ & $\begin{array}{c}\text { HS-OVX } \\
\text { (12) }\end{array}$ \\
\hline BW $(\mathrm{g})$ & $230.4 \pm 4.499$ & $261^{a} \pm 5.478$ & $251^{\mathrm{a}} \pm 7.661$ \\
\hline BMI $\left(\mathrm{g} / \mathrm{cm}^{2}\right)$ & $0.492 \pm 0.008$ & $0.568^{a} \pm 0.013$ & $0.549^{\mathrm{a}} \pm 0.016$ \\
\hline VFwt (g) & $10.008 \pm 0.856$ & $11.27 \pm 1.841$ & $9.233 \pm 1.015$ \\
\hline WC (cm) & $14.16 \pm 0.154$ & $15.16^{\mathrm{a}} \pm 0.248$ & $14.58^{\mathbf{b}} \pm 0.148$ \\
\hline VFwt/BW & $0.044 \pm 0.004$ & $0.043 \pm 0.007$ & $0.037 \pm 0.004$ \\
\hline
\end{tabular}

a: statistically significant from SHAM

b: statistically significant from OVX

Changes in plasma glucose, glucose uptake by diaphragm (glu- uptake), and glucose output by the kidney (gluoutput), serum Insulin and homeostatic model assessment of insulin resistance (HOMA-IR):

In table (2), ovariectomized group showed significant increase in plasma level of glucose, serum insulin and HOMA-IR, however significant decrease in glucose uptake by diaphragm and statistically non-significant change in glucose output by kidneys as compared to the control group. High salt

Table (2): Mean \pm SEM of plasma glucose, glucose uptake by diaphragm (Gluuptake), glucose output by the kidney (Glu-output), Serum Insulin (Insulin) and Homeostatic model assessment of insulin resistance (HOMAIR) in all studied groups.

\begin{tabular}{|c|c|c|c|}
\hline Parameters & SHAM & OVX & HS-OVX \\
\hline $\begin{array}{c}\text { Glucose } \\
\text { (mg/dl) }\end{array}$ & $98.22 \pm 2.683$ & $150.3^{\mathbf{a}} \pm 8.059$ & $159.9^{\mathbf{a}} \pm 5.141$ \\
\hline $\begin{array}{c}\text { Glu-uptake } \\
\text { (mg/g/90min) }\end{array}$ & $92.32 \pm 10.38$ & $53.23^{\mathbf{a}} \pm 9.149$ & $49.81^{\mathbf{a}} \pm 10.60$ \\
\hline $\begin{array}{c}\text { Glu- output } \\
\text { (mg/g/60min) }\end{array}$ & $0.388 \pm 0.079$ & $.387 \pm 0.080$ & $.472 \pm 0.058$ \\
\hline $\begin{array}{c}\text { Insulin } \\
\text { (ng/ml) }\end{array}$ & $0.130 \pm 0.016$ & $0.680^{\mathbf{a}} \pm 0.060$ & $0.822^{\mathbf{a}, \mathbf{b}} \pm 0.039$ \\
\hline HOMA-IR & $0.934 \pm 0.136$ & $7.497^{\mathbf{a}} \pm 0.941$ & $9.404^{\mathbf{a}, \mathbf{b}} \pm 0.617$ \\
\hline
\end{tabular}

a: statistically significant from SHAM

b: statistically significant from OVX ovariectomized group showed significant increase in serum insulin level and HOMA-IR as compared to ovariectomized group, however, the increase in plasma glucose level and glucose output and the decrease in glucose uptake were nonsignificantly changed. Meanwhile, high salt ovariectomized group showed significant increase in plasma level of glucose and serum insulin and HOMA-IR and significant decrease in glucose uptake but non-significant increase in glucose output as compared to the control group. 
Changes in plasma levels of triglycerides (TG), total cholesterol (TC), high density lipoprotein (HDL-C) and low density lipoprotein (LDL-C) and atherogenic index (AI):

In table (3), both ovariectomized group and high salt ovariectomized group showed significant increase in plasma levels of TG, TC, LDL-C and $\mathrm{AI}$ and significant decrease in plasma HDL-C level as compared to control group. However, insignificant changes were found in high salt ovariectomized group when compared to the ovariectomized group.

Table (3): Mean \pm SEM of plasma triglycerides (TG), total cholesterol (TC), high density lipoprotein (HDL-C), low density lipoprotein (LDL-C) and atherogenic index (AI) in all studied groups.

\begin{tabular}{|c|c|c|c|}
\hline Groups & $\begin{array}{c}\text { SHAM } \\
\text { Parameters }\end{array}$ & $\begin{array}{c}\text { OVX } \\
(\mathbf{1 2})\end{array}$ & $\begin{array}{c}\text { HS-OVX } \\
(\mathbf{1 2})\end{array}$ \\
\hline $\begin{array}{c}\text { TG } \\
(\mathbf{m g} / \mathbf{d l})\end{array}$ & $51.58 \pm 2.512$ & $98.06^{\mathrm{a}} \pm 3.214$ & $96.75^{\mathrm{a}} \pm 1.880$ \\
\hline $\begin{array}{c}\text { TC } \\
(\mathbf{m g} / \mathbf{d l})\end{array}$ & $76.24 \pm 3.190$ & $114.23^{\mathrm{a}} \pm 3.599$ & $115.3^{\mathrm{a}} \pm 1.241$ \\
\hline $\begin{array}{c}\text { HDL-C } \\
(\mathbf{m g} / \mathbf{d l})\end{array}$ & $42.44 \pm 1.445$ & $27.59^{\mathrm{a}} \pm 0.627$ & $29.84 \pm 0.623$ \\
\hline $\begin{array}{c}\text { LDL-C } \\
(\mathbf{m g} / \mathbf{d l})\end{array}$ & $14.47 \pm 1.861$ & $97.04^{\mathrm{a}} \pm 3.113$ & $66.23^{\mathrm{a}} \pm 1.217$ \\
\hline AI & $1.582 \pm 0.050$ & $3.629^{\mathrm{a}} \pm 0.106$ & $3.868^{\mathbf{a}} \pm 0.115$ \\
\hline
\end{tabular}

a: statistically significant from SHAM

Changes in plasma catalase and serum estradiol, malondialdehyde (MDA) and tumor necrosis factor $-\alpha(T N F-\alpha)$ in all studied groups:

In table (4), both ovariectomized group and high salt ovariectomized group showed significant decrease in serum estradiol level and significant increase in levels of MDA, TNF- $\alpha$ and catalase as compared to the control group. High salt ovariectomized group showed significant increase in levels of MDA and TNF- $\alpha$, together with non-significant increase in level of catalase and non-significant decrease in estradiol level as compared to ovariectomized group.

Table (4): Mean \pm SEM of plasma catalase and serum estradiol, malondialdehyde (MDA) and tumor necrosis factor $-\alpha(\mathrm{TNF}-\alpha)$ in all studied groups.

\begin{tabular}{|c|c|c|c|}
\hline Groups & $\begin{array}{c}\text { SHAM } \\
\text { Parameters }\end{array}$ & $\begin{array}{c}\text { OVX } \\
(\mathbf{1 2})\end{array}$ & $\begin{array}{c}\text { HS-OVX } \\
(\mathbf{1 2})\end{array}$ \\
\hline $\begin{array}{c}\text { Estradiol } \\
(\mathbf{p g} / \mathbf{m l})\end{array}$ & $59.93 \pm 1.602$ & $10.28^{\mathbf{a}} \pm 1.079$ & $8.436^{\mathbf{a}} \pm 0.822$ \\
\hline $\begin{array}{c}\text { MDA } \\
(\mathbf{n m o l} / \mathbf{m l})\end{array}$ & $15.46 \pm 1.422$ & $81.20^{\mathbf{a}} \pm 5.874$ & $103.3^{\mathbf{a}, \mathbf{b}} \pm 4.599$ \\
\hline $\begin{array}{c}\text { Catalase } \\
(\mathbf{U} / \mathbf{L})\end{array}$ & $543.2 \pm 30.88$ & $778.6^{\mathbf{a}} \pm 028.92$ & $793.9^{\mathbf{a}} \pm 10.47$ \\
\hline $\begin{array}{c}\text { TNF- } \boldsymbol{\alpha} \\
(\mathbf{p g} / \mathbf{m l})\end{array}$ & $18.85 \pm 10.843$ & $98.13^{\mathbf{a}} \pm 5.987$ & $120.98^{\mathbf{a}, \mathbf{b}} \pm 4.229$ \\
\hline
\end{tabular}

a: statistically significant from SHAM

b: statistically significant from OVX 
Histopathological study:

\section{1) Pancreas:}

\section{a. Hematoxylin \& Eosin (H\&E):}

In the pancreas of sham operated control group, the islet of Langerhans were seen scattered in-between the acini, and appeared as a paler structure formed of clusters of different cells (Fig. 1a). In ovariectomized rats, some of islets appeared with fewer number in cells, and most of them were attenuated with very few or absent cells in the center* (Fig. 1b). In ovariectomized-high salt group, some of the pancreatic lobules appeared with increased number of islets of Langerhans, while others appeared with fatty degeneration $\rightarrow$ (Fig.1c).

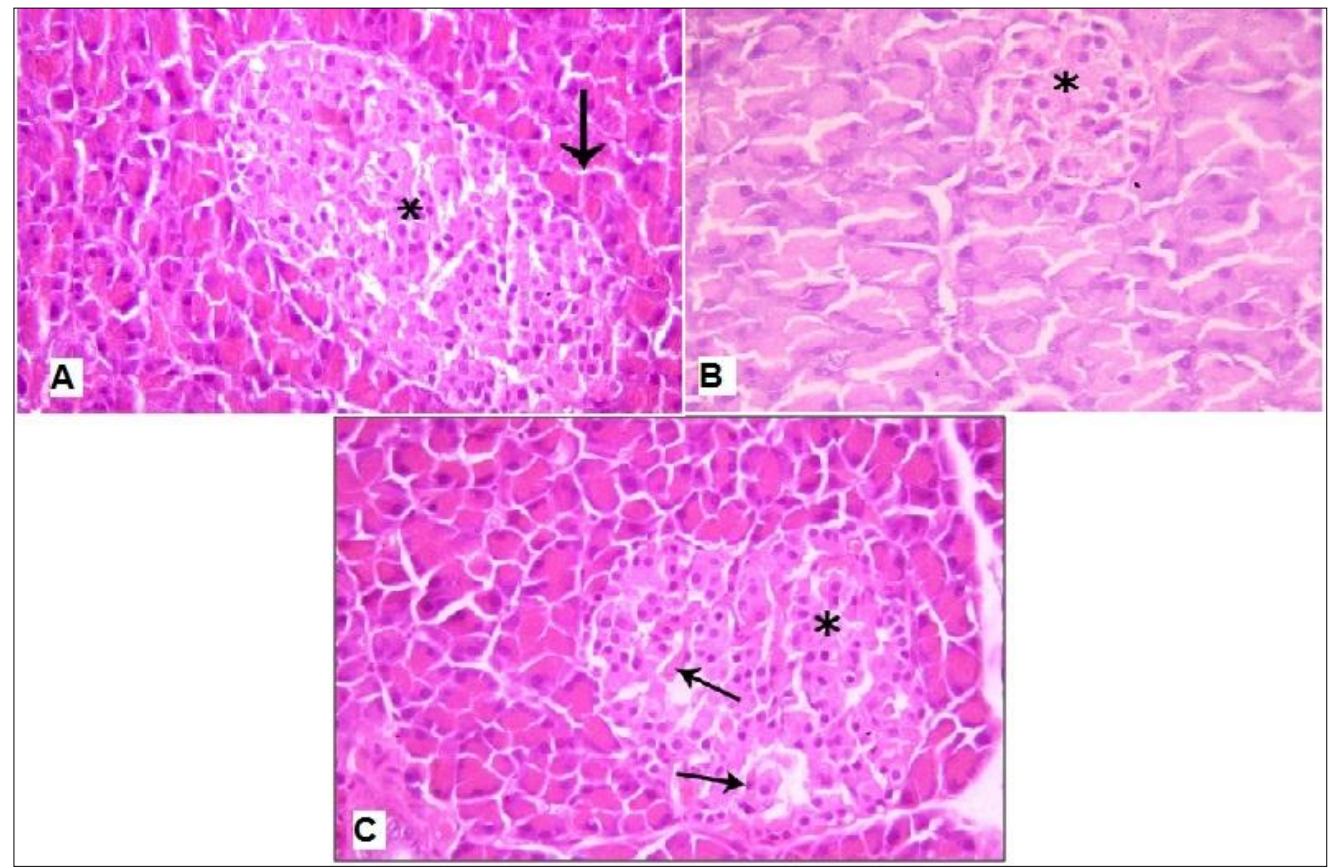

Figure (1): Photomicrograph of the pancreas tissue sections H\&E 400 A: sham-operated group, B: ovarievtomized group, C: high salt ovariectomized group.

b. Caspase-3- immunostaining:

In sham operated control group, the pancreas showed islets of Langerhans with mild positive immune reaction for caspase-3 (Fig. 2a). In ovariectomized rats, the islets showed moderate positive immune reaction for caspase-3 (Fig. 2b). In ovariectomized-high salt group, prominent positive immune reaction for caspase-3 appeared (Fig. 2c). 


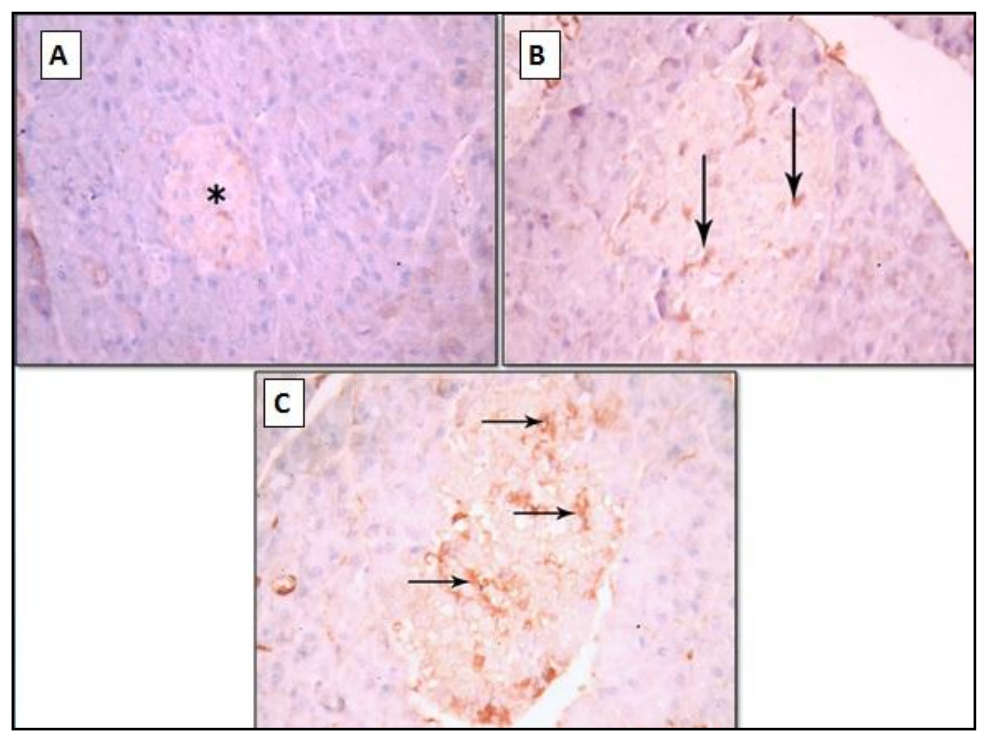

Figure (2): Photomicrograph of the pancreas tissue sections Caspase-3 $\times 400$ A: sham-operated group, B: ovarievtomized group, C: high salt ovariectomized group.

\section{Liver:}

\section{a. Hematoxylin \& Eosin (H\&E):}

Hepatocytes, in the control group were seen polygonal in shape with vesicular nuclei and acidophilic cytoplasm separated by hepatic sinusoids. Portal tract were seen in the periphery of the hepatic lobule (Fig. 3a). Examination of the portal area, appeared containing bile ducts, branches from the hepatic artery and branches from the portal vein with few lymphocytes (Fig.4a).

In ovariectomized group the liver showed irregular organization of hepatocyte cords with dilated blood sinusoids (Fig. 3b). The portal areas seen with thickened congested portal vein and moderate lymphocytic infiltration (Fig. $4 b)$.

Liver of the high salt ovariectomized group showed irregular organization of hepatocyte cords. Most of the hepatocytes appeared swollen vacuolated with fatty degeneration (liver ballooning). Some degenerated with pyknotic nuclei (Fig. $3 c)$. The portal area showed severe lymphocytic infiltration in (Fig. 4c). 


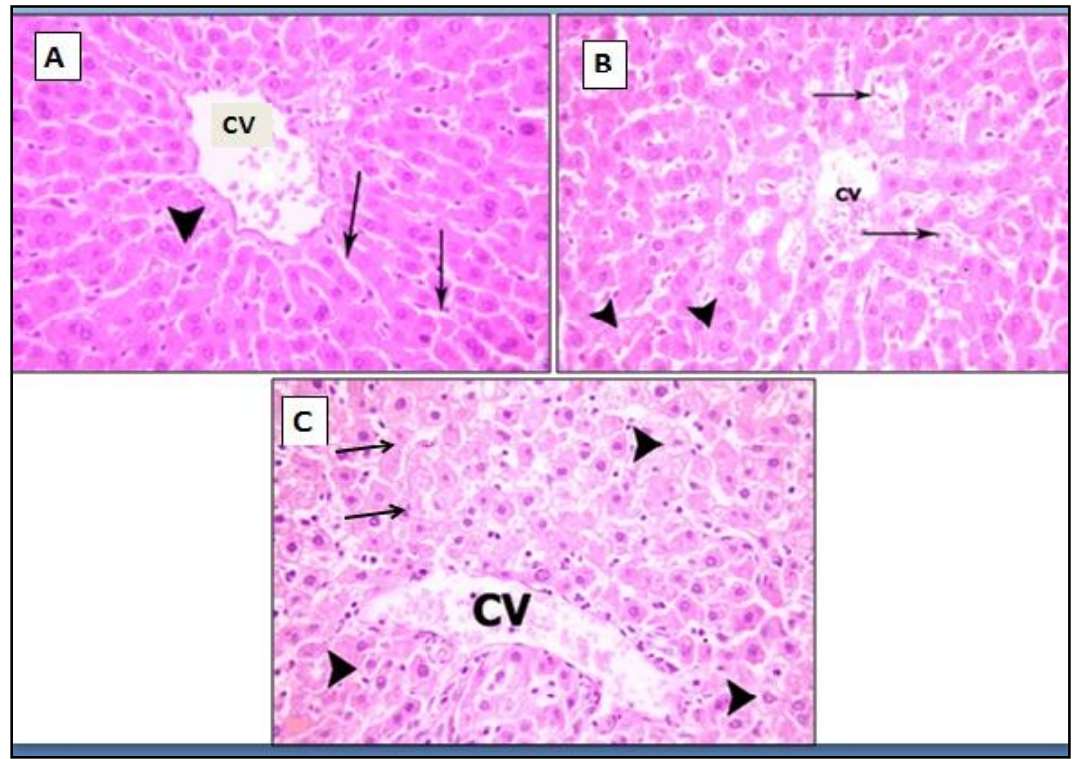

Figure (3): Photomicrograph of the liver tissue sections H\&E $\times 400$ A: sham-operated group, B: ovarievtomized group, C: high salt ovariectomized group.

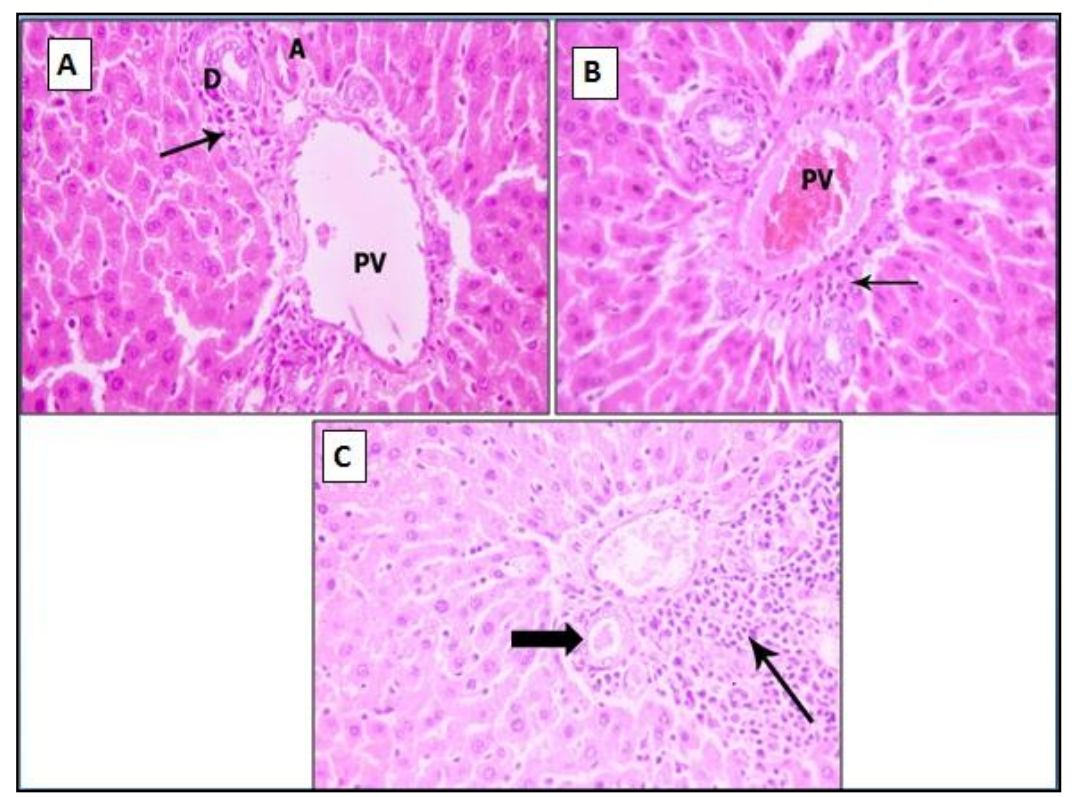

Figure (4): Photomicrograph of the portal areas in liver tissue sections H\&E $\times 400$ A: sham-operated group, B: ovarievtomized group, C: high salt ovariectomized group.

\section{b. Masson's trichome stain:}

The portal tract showed minimal collagen fibers distribution in the control group (Fig. 5a). In ovariectomized group, there was an increase in the amount of collagen fibers deposits which was most prominent around the portal tract (Fig. $5 b)$. In high salt group, massive peripheral collagen fibers deposits were observed (Fig. 5c). 


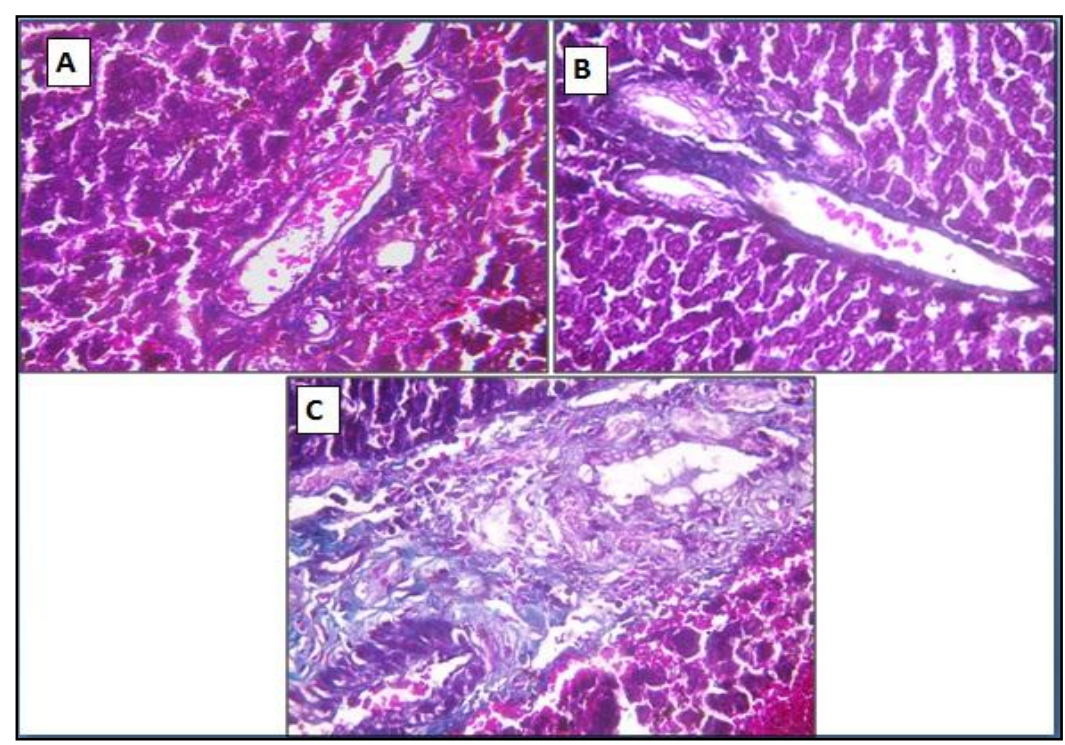

Figure (5): Photomicrograph of the portal areas in liver tissue sections Masson's trichrome $\times 400$

A: sham-operated group, B: ovarievtomized group, C: high salt ovariectomized group.

\section{DISCUSSION}

The present study was planned to determine the possible effects of salt loading on disturbed glucose and lipid homeostasis in postmenopausal- like model of ovariectomized rats, with an attempt to clarify the potential underlying mechanism(s).

Successful induction of ovariectomy in the studied rats was denoted by the significant reduction of serum estradiol in the ovariectomized group and high salt ovariectomized group as compared to the control group.

Ovariectomized rats exhibited significant increase in final body weight, waist circumference and final BMI. Upon high salt intake, these parameters insignificantly changed, while waist circumference significantly decreased compared to ovariectomized group.
These results denoted occurrence of obesity following ovariectomy. Estradiol exerts anorexic effect by stimulating the production of serotonin in the central nervous system (Benmansour et al., 2014) as well as stimulating the anorexigenic proopiomelanocortin and cocaineamphetamine-regulated transcript activitywhich inhibit food intake and increase energy expenditure and inhibiting orexigenic neuropeptide $\mathrm{Y}$ and Agoutirelated peptide neurons which stimulate food intake and decrease energy expenditure in the hypothalamic arcuate nucleus (Hirschberg, 2012).

In the present study, high salt ovariectomized group displayed a state of lower adiposity. This could be attributed to suppression of digestive efficiency via inhibition of renin -angiotensin system according to the study of Weidemann et al. (2015). 
This finding contradicted with studies in both humans and experimental animals relating obesity to high salt consumption. High sodium intake was found to cause obesity by increasing the desire to eat certain types of food and beverages (Navia et al., 2014), or independent of total energy intake (Yuan et al., 2015). Moreover, Kang et al. (2018) found that two-month low salt diet was accompanied by reduction of body mass index due to reduction of total body water and not by reduction of body fat mass or visceral fat mass.

The obtained glycemic data including hyperglycemia and diminished glucose uptake by diaphragm following ovariectomy indicated the occurrence of insulin resistance and reduction of insulin sensitivity that could be attributed to estrogen deficiency.

Estrogen deficiency-mediated diminution of glucose uptake could be attributed to decrease expression of glucose transporter GLUT4 in skeletal muscle that was recovered after estradiol treatment (Inada et al., 2016).

Furthermore, oxidative stress could be another mechanism contributing in the deranged glucose homeostasis, insulin resistance and dyslipidemia observed in the current work. Ovariectomized rats demonstrated high serum levels of MDA, the oxidative damage indicator and catalase (the antioxidant defense mechanism).

In agreement, an elevated level of MDA was demonstrated in several previous studies conducted in postmenopausal women (Cakir et al., $2016)$ as well as in ovariectomized rats ( $E l$ Habachi et al., 2014).
A contrasting finding was observed by Victorino et al. (2012) who found that postmenopausal women had lower levels of lipid hydroperoxide oxidation, and the MDA levels did not differ between preand postmenopausal women.

As obtained in the current work, studies by Radtke et al. (2011) and Castanho et al. (2012) showed that the catalase enzyme was significantly higher in postmenopausal women compared with reproductive women and its level declined in postmenopausal women after hormonal therapy with estrogen or progesterone.

In the current study, although serum catalase activity increased, it was unable to counterbalance the oxidative stress as the high MDA levels indicate that the amount of lipid peroxidation exceeded the capacity of antioxidant defenses for their neutralization. Thus, high catalase lost its ability to scavenge the end product of lipid peroxidation, MDA, and was unable to reverse the oxidative process promoted by ovariectomy.

The results of glycemic parameters and insulin resistance following ovariectomy, observed in the present study could also be explained by the inflammatory state mediated by estrogen withdrawal as indicated by the elevated level of the proinflammatory cytokine TNF- $\alpha$ in the ovariectomized group. In support, TNF- $\alpha$ was found to cause insulin resistance by enhancing adipocyte lipolysis, impairing insulin signaling via increasing serine/threonine phosphorylation of IRS1(Chen et al. 2015) and decreasing the expression of glucose transporter type-4 (Akash et al, 2018).

Minihane et al. (2015) proposed that pro-inflammatory mediators released from 


\section{HOWIDA A. SALEH et al.,}

adipose tissue following ovariectomy impaired the insulin signaling and induced insulin resistance. Moreover, aggravation of inflammatory state in ovariectomized rats following high fat diet induced diabetes was indicated by high proinflammatory cytokines (ILlb and TNF-a) and low anti-inflammatory cytokines (IL4 and IL10) (Fahmy et al., 2018).

Sharma et al. (2013) showed that obesity leads to lipid accumulation in adipocytes that activate c-Jun $\mathrm{N}$ terminal kinase (JNK) and nuclear factor -kappaB (NF-KB) signaling pathways that subsequently increase the production of proinflammatory cytokines as TNF- $\alpha$ and interleukin-6 (IL-6).

Histological and immunehistochemical studies of pancreas showed fewer cells of islets of Langerhans together with increased number of caspase-3 positive immune-reactive cells indicating presence of apoptosis. Such explanation is based on studies assuming that estrogen protect against apoptosis induced by oxidative stress and inflammatory cytokines (Li et al., 2016).

The high serum TNF- $\alpha$ observed in the ovariectomized group could, also, be a cause of apoptosis (Akash et al. 2012 and Rehman and Akash, 2016) by activating transcriptional factor, NF-kB, which is an important modulator of pancreatic cell death (Donath and Shoelson, 2011).

In addition, apoptosis could be attributed to the high glucose and lipids observed in ovariectomized rats. It has been reported that chronic elevation of cellular glucose and lipids are instrumental in $\beta$ - cell apoptosis (Liu and Mauvais-Jarvis, 2010).
In spite of decrease $\beta$ cell mass, the high serum insulin level could be explained by increased $\beta$ cell compensation. Choi et al. (2013) showed that the pancreas of ovariectomized rats developed proliferating cells around both interlobular and interlobar ducts and some of them were immune positive (secretory for insulin). These changes reflected a compensating mechanism for $\beta$ cell destruction or functional insufficiency. Furthermore, Fahmy et al. (2018) found that pancreatic islets of ovariectomized high fat diet induced diabetic rats showed hyperplasia and proliferating cells around interlobular and interlobar ducts, indicating higher degree of $\beta$ cells compensation.

Furthermore, in the present study, an atherogenic lipid profile was obtained in ovariectomized group, as shown by significant elevation in plasma TG, TC, LDL-C and AI associated with significant reduction in HDL-C and AI. This pattern leads to development and progression of atherosclerosis and increases risk of cardiovascular disease. The deprivation of estrogen is implicated in this hyperlipidemic profile.

These findings are in agreement with Kilim and Chandala (2013) who observed that lipid and lipoprotein metabolism were markedly altered in postmenopausal women and found that menopause was associated with an increase in concentrations of TG, TC, LDL-C and decrease in concentrations of HDL-C.

Moreover, the observed atherogenic lipid profile in the ovariectomized rats could be attributed to increased intestinal absorption of dietary lipids, increased denovo synthesis and inhibition of 
catabolism of cholesterol or fatty acids in liver (Palmisano et al., 2017). Estrogen deficiency in ovariectomized rats was found to downregulate expression of enzymes involved in bile acid synthesis decreasing cholesterol removal from the blood (Liao et al., 2015).

The liver of ovariectomized group showed focal involvement of most lobules with fatty change, some cells advanced to ballooning and there was some lobular inflammation with minimal fibrosis. The present data are similar to the results of Jeong et al. (2018) showing fat accumulation, ballooning and infiltrating inflammatory cells in liver of ovariectomized mice. Hepatocyte ballooning is a histological hallmark of cellular injury and cytoskeletal damage (Tandra et al., 2011).

In agreement, Villa et al. (2012) showed that ovariectomy is associated with the rapid alteration of lipid metabolism and increased lipid deposits in the liver.

The fatty changes in the liver of ovariectomized rats indicate high fat content of the liver which could be explained by several mechanisms. It could be attributed to excessive food intake as ovariectomized rats gained more weight and their waist circumference was increased compared to sham group. Such explanation is in accordance to Eshtiaghi et al. (2010) who reported that ovariectomy in mice and menopause in women are associated with increased weight, decreased lean mass, increased lipids in the liver and accumulated visceral white adipose tissue.

A second explanation could be the associated insulin resistance that leads to accumulation of triacylglycerols in hepatocytes, an explanation in accordance to the study of De Oliveira et al., (2018). Also, ovariectomy induced hypertriglyceridemia may have caused fat accumulation in the liver (Palmisano et al., 2017). Benedusi et al. (2015) reported that the accumulation of fat increases mitochondrial $\beta$-oxidation and the production of reactive oxygen species with insufficient suppression of lipolysis, and also, promotes recruitment and activation of macrophages that initiate the secretion of proinflammatory factors in both fat and the liver.

In the present study, high salt ovariectomized group exhibited significant increase in serum insulin and HOMA-IR compared to ovariectomized group which denote exaggeration of the hyperinsulinemia and insulin resistance by salt loading.

Meanwhile, in pancreatic histopathological examination, some of pancreatic lobules appeared with fatty degeneration. Thus, the higher insulin level following salt intake could be explained by the great number of cells of Langerhans, which is a sign of compensatory $\beta$ cell growth that increase insulin biosynthesis causing a state of compensatory hyperinsulinemia.

It is to be noted that plasma glucose after salt loading was insignificantly increased from ovariectomized group, but was still significantly higher than sham group. This suggests that the compensatory hyperinsulinemia could have prevented the aggravation of hyperglycemia, however, the insulin resistance persisted and was even worsened, a condition that could be 
attributed to associated exaggeration to oxidative and inflammatory states as high salt ovariectomized group showed higher serum levels of MDA and TNF- $\alpha$ as compared to ovariectomized group.

Insulin resistance could also be explained by hyperinsulinemia according to the study of Chow et al. (2019) and Lee (2017) who found that hyperinsulinemia lead to insulin resistance in neurons and insulin resistance with alterations in cellular bioenergetics and activation of inflammatory signaling in lymphatic muscle.

In contrast, Takagi et al. (2018) found that high sodium diet $(8 \% \mathrm{NaCl})$ for 7 weeks ameliorated hyperglycemia and insulin resistance in diabetic fatty rats, which was due to increased plasma levels of adiponectin.

In the present study, hyperlipidemia induced by ovariectomy was not worsened by salt intake. The lower adipogenic state mediated by high salt is assumed to be the explanation as these rats revealed lower final $\mathrm{BW}, \mathrm{BMI}$ and $\mathrm{WC}$ compared to the ovariectomized group. Similar finding was observed in the study of Harsha et al. (2014) which showed that changes in dietary sodium intake over the range of 50 to $150 \mathrm{mmol} / \mathrm{d}$ in humans did not affect blood lipid concentrations.

Huang et al. (2016) observed increased renal $\mathrm{H} 2 \mathrm{O} 2$, MDA and reduced renal total antioxidant capacity and glutathione contents, catalase, glutathione peroxidase GP-PX and superoxide dismutase activity, and superoxide dismutase expressions in Dahl rats after 8 weeks of high-salt $\operatorname{diet}($ $8 \%$ salt).
Increased TNF- $\alpha$ serum level in high salt ovariectomized group in the present work, is in agreement with several studies. Costa et al. (2012) found that high sodium intake was associated with $\mathrm{C}$ reactive protein (CRP) and TNF- $\alpha$ in patient with hypertension and myocardial infarction. Zhu et al., (2014) showed that high sodium intake is positively associated with TNF- $\alpha$ independent of adiposity.

In the current work, high salt administration to ovariectomized rats, resulted in more prominent deterioration in the liver architecture as revealed by diffuse involvement of most of hepatic lobules with inflammation and fibrosis, together with fatty change and hepatocyte ballooning (indicator of degeneration). These marked hepatic changes could be attributed to additive effect of estrogen decline and salt-induced aggravated oxidative stress and inflammatory response.

In support to the present findings, Arima et al. (2014) found that high-salt $\operatorname{diet}(8.0 \% \mathrm{NaCl})$ in rats for 7 weeks, had a potential risk factor for liver injury and hepatic fibrosis due to glucose intolerance and decreased IL-10-mediated (potent anti-inflammatory cytokine) and hemooxygenase (HO-1) induced antiinflammatory effects.

IL-10 also was found to inhibit hepatitis and this inhibition may occur through a mechanism involving increased HO- 1 expression induced by an increase in IL-10 levels (Zhou et al., 2012). In addition, the upregulation of HO-1, as anti-inflammatory was shown to induce a reduction in the levels of cytokines, adhesion molecules, chemokines and 
neutrophil accumulation, and to ameliorate organ injury in a state of shock (Liu et al., 2011).

\section{CONCLUSION}

Ovariectomy, which represents a model of estrogen depletion that mimics the postmenopausal women, is associated with detrimental metabolic profile manifested as weight gain, obesity, hyperglycemia, insulin resistance and hyperlipidemia. These ovariectomypromoted deleterious effects are most likely related to estrogen deprivation together with augmentation of oxidative and inflammatory states.

High salt intake exacerbated the hyperinsulinemia and insulin resistance and intensified pancreatic apoptosis and hepatic fatty and degenerative changes, effects that could be explained by salt loading-induced acceleration and exaggeration of the oxidative and inflammatory influences of ovariectomy.

\section{REFERENCES}

1. Ahmed D., Kumar V., Verma A., Gupta P. S., Kumar H., Dhingra V., Mishra V. and Sharma M. (2014): Antidiabetic, renal/hepatic/pancreas/cardiac protective and antioxidant potential of methanol/dichloromethane extract of Albizzia Lebbeck Benth. stem bark (ALEx) on streptozotocin induced diabetic rats. BMC Complementary and Alternative Medicine; 14:243.

2. Ahmed M. and Abd EL Samad A. (2013): Benefits of omega-3 fatty acid against bone changes in salt-loaded rats: possible role of kidney. Physiol Rep; 1(5): e00106.

3. Akash M.S., Shen Q., Rehman K. and Chen S. (2012): Interleukin-1 receptor antagonist: a new therapy for type 2 diabetes mellitus. J Pharm Sci; 101(5):1647-1658.
4. Akash M.S.H., Rehman K. and Liaqat A. (2018): Tumor Necrosis Factor-Alpha: Role in Development of Insulin Resistance and Pathogenesis of Type 2 Diabetes Mellitus. J Cell Biochem; 119(1):105-110.

5. Arima S., Uto H., Ibusuki R., Kumamoto R., Tanoue S., Mawatari S., Oda K., Numata M., Fujita H., Oketani M., Ido A. and Tsubouchi H. (2014): Hypertension exacerbates liver injury and hepatic fibrosis induced by a choline-deficient L-amino aciddefined diet in rats. International Journal of Molecular Medicine; 33: 68-76.

6. Bancroft J.D. and Gamble M. (2002): Theory and practice of Histological Techniques. 5th. edition. Churchill Livingstone. London, New York \& Sydney. 377-694.

7. Benedusi V., Martini E., Kallikourdis M., Villa A., Meda C. and avid Maggi A. (2015): Ovariectomy shortens the life span of female mice. Oncotarget, 6(13):10801-11.

8. Benmansour S., Privratsky A.A., Adeniji O.S. and Frazer A. (2014): Signaling mechanisms involved in the acute effects of estradiol on 5-HT clearance. Int. J. Neuropsychopharmacol., 17:765-777.

9. Brey C.W., Akbari-Alavijeh S., Ling J., Sheagley J., Shaikh B., Al-Mohanna F., Wang Y., Gaugler R. and Hashmi S. (2019): Salts and energy balance: A special role for dietary salts in metabolic syndrome. Clin Nutr., 38(5):1971-1985.

10. Cakir T., Goktas B., Mutlu M. F., Mutlu I., Bilgihan A., Erdem M. and Erdem A.( 2016): Advanced oxidation protein products and malondialdehyde - the new biological markers of oxidative stress-are elevated in postmenopausal women. Ginekologia polska; 87, (5) 321-325.

11. Castanho V.S., Nakamura R.T., PintoNeto A.M. and de Faria E.C. (2012): Postmenopausal Therapy Reduces Catalase Activity and Attenuates Risk. Original article. Arb Bras Cardiol.; 99(5): 1008-1014.

12. Chen L., Chen R., Wang H. and Liang F. (2015): Mechanisms Linking Inflammation 


\section{HOWIDA A. SALEH et al.,}

to Insulin Resistance. Int $\mathbf{J}$ Endocrinol; 508409 .

13. Choi J.E., Noh S.J., Sung J.J. and Moon W.S. (2013): Nesidioblastosis and pancreatic nonfunctioning islet cell tumor in an adult with type 2 diabetes mellitus. Korean J Path., 47: 489-491.

14. Chow H.M., Shi M., Cheng A., Gao Y., Chen G., Song X., So R.W.L., Zhang J. and Herrup K. (2019): Age-related hyperinsulinemia leads to insulin resistance in neurons and cell-cycle-induced senescence. Nat Neurosci., 22(11): 18061819.

15. Chung G.E., Yim J.Y., Kim D., Lim S.H., Yang J.I., Kim Y.S., Yang S.Y., Kwak M.S., Kim J.S. and Cho S.H. (2015): The influence of metabolic factors for nonalcoholic Fatty liver disease in women. Biomed Res Int., 2015:131528.

16. Cogswell M.E., Mugavero K., Bowman B.A. and Frieden T.R. (2016): Dietary Sodium and Cardiovascular Disease Risk Measurement Matters. N Engl J Med., 375(6): 580-586.

17. Costa A.P., de Paula R.C., Carvalho G.F., Araújo J.P., Andrade J.M., de Almeida O.L., de Faria E.C., Freitas W.M., Coelho O.R., Ramires J.A., Quinaglia e Silva J.C. and Sposito A.C. (2012): Brasilia Heart Study Group. High sodium intake adversely affects oxidative-inflammatory response, cardiac remodeling and mortality after myocardial infarction. Atherosclerosis; 222(1):284-291.

18. Dalal P.K. and Agarwal M. (2015): Postmenopausal syndrome. Indian J Psychiatry, 57(2): 222-232.

19. De Oliveira E., Lima N.S., Conceição E.P.S., Peixoto-Silva N., Moura E.G. and Lisboa P.C. (2018): Treatment with Ilex paraguariensis (yerba mate) aqueous solution prevents hepatic redox imbalance, elevated triglycerides, and microsteatosis in overweight adult rats that were precociously weaned. Braz J Med Biol Res; 51(6): e7342.
20. Donath M.Y. and Shoelson S.E. (2011): Type 2 diabetes as an inflammatory disease. Nat Rev Immunol.; 11(2): 98-107.

21. Drury R.A., Wallington E.A. and Cancerson R., Eds. (1976): Carlton's Histopathological Techniques. 4th Edition, Oxford University Press, Oxford, London, New York.

22. El Habachi N.M., Maklad H.M., Sharara G.M., Allam E.A. and Fawzy E.M. (2014): A comparative study between the effect of $17-\beta$ estradiol and antioxidants combination on some menopausal changes in oophorectomised rats. Middle East Fertility Society Journal; 19(4): 303-313.

23. El-Nasr A.S., Diab F.M.A., Bahgat N.M., Ahmed M.A., Thabet S.S. and El-Dakkak S.M.Y. (2011): Metabolic effects of estrogen and/or insulin in ovariectomized experimentally diabetic rats. Journal of American Science, 7(2): 432-444.

24. Eshtiaghi R., Esteghamati A. and Nakhjavani M. (2010): Menopause is an independent predictor of metabolic syndrome in Iranian women. Maturitas, 65: 262-266.

25. Fahmy M., Sayyed H., Abd Elrahim E. and Farag R. (2018): Superimposed effect of ovariectomy on type 2 diabetes mellitus in Wistar rats. Alexandria Journal of Medicine, 54: 129-137.

26. Friedewald W.T., Levy R.I. and Frederickson D.S. (1972): Estimation of the concentration of low-density lipoprotein cholesterol in plasma, without use of the preparative ultracentrifuge. Clinical Chemistry, 18(6): 499-502.

27. Gibb F., Dixon J., Clarke C., Homer N., Faqehi A., Andrew R., and Walker B. (2019): Higher Insulin Resistance and Adiposity in Postmenopausal Women with Breast Cancer Treated with Aromatase Inhibitors J Clin Endocrinol Metab., 104(9): 3670-3678.

28. Grundy S.M., Greenland P.H. and Herd L. (1987): Cardiovascular and risk factor evaluation of healthy American adult. Circulatio.; 75: 2340A. 
29. Harsha D.W., Sacks F.M., Obarzanek E., Svetkey L.P., Lin P.H., Bray G.A., Aickin M., Conlin P.R., Miller E.R. 3rd and Appel L.J. (2004): Effect of dietary sodium intake on blood lipids: results from the DASHsodium trial. Hypertension; 43(2): 393-398.

30. Hirschberg A.L. (2012): Sex hormones, appetite and eating behaviour in women Angelica Lindén Hirschberg. Maturitas; 71: 248-256.

31. Huang P., Shen Z., Liu J., Huang Y., Chen S., Yu W., Wang S., Ren Y., Li X., Tang C., Du J. and Jin H. (2016): Hydrogen Sulfide Inhibits High-Salt Diet-Induced Renal Oxidative Stress and Kidney Injury in Dahl Rats. Oxid Med Cell Longev.; 2016:2807490.

32. Inada A, Fujii N.L., Inada O., Higaki Y., Furuichi Y. and Nabeshima Y. (2016): Effects of $17 \beta$-Estradiol and Androgen on Glucose Metabolism in Skeletal Muscle. Endocrinology; 157 (12): 4691-4705.

33. Ingie M. and Griffith J.O. (1949): The rat in laboratory investigation (1949) 2nd Edition, Lippin Cott. J. B. company. Green; 31(9): 287-288.

34. Jeong Y.H., Hur H.J., Jeon E.J., Park S.J., Hwang J.T., Lee A.S., Lee K.W. and Sung M.J. (2018): Honokiol Improves Liver Steatosis in Ovariectomized Mice. Molecules; 23(1): 194.

35. Kang H.J., Jun D.W., Lee S.M., Jang E.C. and Cho Y.K. (2018): Low salt and lowcalorie diet does not reduce more body fat than same calorie diet: a randomized controlled study. Oncotarget; 9(9): 85218530 .

36. Kilim R.S and Chandala, S.R. (2013): A comparative study of lipid profileand oestradiol in pre- and post-menopausal women. J. Clin. Diagn.; Res.; 7: 1596-1598.

37. Lanaspa M.A., Kuwabara M., AndresHernando A., Li N., Cicerchi C., Jensen T., Orlicky D.J., Roncal-Jimenez C.A., Ishimoto T., Nakagawa T., RodriguezIturbe B., MacLean P.S. and Johnson R.J. (2018): High salt intake causes leptin resistance and obesity in mice by stimulating endogenous fructose production and metabolism. Proc Natl Acad Sci USA; 115(12): 3138-3143.

38. Lee Y., Fluckey JD., Chakraborty S. and Muthuchamy M. (2017): Hyperglycemiaand hyperinsulinemia-induced insulin resistance causes alterations in cellular bioenergetics and activation of inflammatory signaling in lymphatic muscle. FASEB J. ; 31(7):2744-2759.

39. Li H., Zhu C., Wang B., Zhu W., Feng Y., Du F., Wang S., Hu C., Ma J., Yu X. (2016): 17 $\beta$-Estradiol Protects the Retinal Nerve Cells Suppressing TLR2 Mediated Immune-Inflammation and Apoptosis from Oxidative Stress Insult Independent of PI3K. J Mol Neurosci.; 60: 195-204

40. Liao C.C., Chiu Y.S., Chiu W.C., Tung Y.T., Chuang H.L., Wu J.H. and Huang C.C. (2015): Proteomics Analysis to Identify and Characterize the Molecular Signatures of Hepatic Steatosis in Ovariectomized Rats as a Model of Postmenopausal Status. Nutrients; 7(10): 8752-8766.

41. Liu F., Mu J., Yuan Z., Wu G., Liu E., Zheng S., Lian Q, Ren K. and Xu $H$. (2012): High salt intake fails to enhance plasma adiponectin in normotensive saltsensitive subjects. Nutrition; 28(4): 422-425.

42. Liu F.C., Hwang T.L., Lau Y.T. and Yu H.P. (2011): Mechanism of salutary effects of astringinin on rodent hepatic injury following trauma-hemorrhage: Aktdependent hemeoxygenase-1 signaling pathways. PLoS One.; 6(10): e25907.

43. Liu S. and Mauvais-Jarvis F. (2010): Minireview: Estrogenic protection of betacell failure in metabolic diseases. Endocrinology; 151(3): 859-864.

44. Logue J., Walker J.J., Colhoun H.M., Leese G.P., Lindsay R.S., McKnight J.A., Morris A.D., Pearson D.W., Petrie J.R., Philip S., Wild SH, and Sattar N. (2011): Do men develop type 2 diabetes at lower body mass indices than women? Scottish Diabetes Research Network Epidemiology Group. Diabetologia.; 54(12) :3003-6. 
45. Matthews D.R., Hosker J.P., Rudenski A.S., Naylor B.A., Treacher D.F. and Turner R.C. (1985): Homeostasis model assessment: insulin resistance and beta-cell function from fasting plasma glucose and insulin concentrations in man. Diabetologia; 28(7): 412-419.

46. Minihane A.M., Vinoy S., Russell W.R., Baka A., Roche H.M., Tuohy K.M., Teeling J.L., Blaak E.E., Fenech M., Vauzour D., McArdle H.J., Kremer B.H., Sterkman L., Vafeiadou K., Benedetti M.M., Williams C.M. and Calder P.C. (2015): Low-grade inflammation, diet composition and health: Current research evidence and its translation. Br J Nutr.; 114: 999-1012.

47. Mohamed A.H., Ayobe M.H., Beskharoun M.A. and El-Damarawy N.A. (1975): Effect of cholera venom (Naja Haje) on adipose tissue and muscles metabolism. Ain Shams Med. J.; 26: 693-699.

48. Navia B., Aparicio A., Perea JM, PérezFarinós N., Villar-Villalba C., Labrado E. and Ortega R.M. (2014): Sodium intake may promote weight gain; results of the FANPE study in a representative sample of the adult Spanish population. Nutr Hosp.; 29(6): 1283-9.

49. Palmisano B.T., Zhu L., and Stafford J.M. (2017): Role of Estrogens in the Regulation of Liver Lipid Metabolism. Advances in Experimental Medicine and Biology; 1043: 227-256.

50. Radtke V., Terhorst L., Cohen S.M. and shrivastava T. (2011): The menopausespecific Quality of life (menQol) Questionnaire: psychometric Evaluation among Breast Cancer Survivors. Menopause; 18(3): 289-95.

51. Randall H.M. (1972): Metabolic and functional effects of acute renal ischemia in dog kidney slices. American Journal of Physiology; 223(4): 756-762.

52. Rehman K., and Akash M.S. (2016): Mechanisms of inflammatory responses and development of insulin resistance: how are they interlinked? J Biomed Sci.; 23(1):87.
53. Sharma M., Vikram NK, Misra A., Bhatt S., Tarique M., Parray HA, Pandey RM and Luthra K (2013): Assessment of 11- $\beta$ hydroxysteroid dehydrogenase (11- $\beta$ HSD1) $4478 \mathrm{~T}>\mathrm{G}$ and tumor necrosis factor- $\alpha$ (TNFa)-308G>A polymorphisms with obesity and insulin resistance in Asian Indians in North India. Mol Biol Rep.; 40(11):6261-70.

54. Takagi Y., Sugimoto T., Kobayashi M., Shirai M. and Asai F (2018): High-Salt Intake Ameliorates Hyperglycemia and Insulin Resistance in WBN/Kob-Leprfa/fa Rats: A New Model of Type 2 Diabetes Mellitus. Journal of Diabetes Research; 3671892: 1-9.

55. Tandra S., Yeh MM, Brunt EM, Vuppalanchi R., Cummings OW, ÜnalpArida A., Wilson LA and Chalasani N (2011): Presence and significance of microvesicular steatosis in nonalcoholic fatty liver disease. J Hepatol. ; 55(3):654-659.

56. Tawfik S.H., Mahmoud B.F., Saad M.I., Shehata M., Kamel M.A., and Helmy, M.H. (2015): Similar and Additive Effects of Ovariectomy and Diabetes on Insulin Resistance and Lipid Metabolism. Biochemistry Research International, Article ID 567945, 1-8.

57. Victorino V. J., Panis C., Campos F. C., Cayres R. C., Colado-Simão A. N., Oliveira S. R., Herrera A. C., Cecchini A. L and Cecchini R (2013): Decreased oxidant profile and increased antioxidant capacity in naturally postmenopausal women. Age (Dordr); 35(4):1411-21.

58. Villa A., Della Torre S., Stell A., Cook J., Brown M., and Maggi A (2012): Tetradian oscillation of estrogen receptor alpha is necessary to prevent liver lipid deposition. Proc Natl Acad Sci U S A; 109:11806-11811.

59. Weidemann BJ, Voong S., MoralesSantiago FI, Kahn MZ, Ni J., Littlejohn NK, Claflin KE, Burnett CM, Pearson NA, Lutter ML. and Grobe JL (2015): Dietary Sodium Suppresses Digestive Efficiency via the Renin-Angiotensin System. Sci Rep. ;11; 5:11123

60. Yuan F., Guo ZZ, Ji WJ, Ma YQ, Zhang Z., Zhou X. and Li YM (2015): BOLD-MRI 
evaluation of subcutaneous and visceral adipose tissue oxygenation status: effect of dietary salt intake. Am J Transl Res.; 7(3):598-606.

61. Zhou YC, Chen S., Cao JJ, Chen SY, Xie YF and Niu QX (2012): Adenovirusmediated viral interleukin-10 gene transfer prevents concanavalin A-induced liver injury. Dig Liver Dis.; 44: 398-405.

62. Zhu H., Pollock NK, Kotak I., Gutin B., Wang X., Bhagatwala J., Parikh S., Harshfield GA and Dong Y (2014): Dietary sodium, adiposity, and inflammation in healthy adolescents. Pediatrics.; 133: e635e642. 
تأثير زبادة تتاول الملح على التخيرات الأبضبة في الفئران المستأصلة للمبيضين المبيز

هويدا أحمد السيد صالح خثب، ـ منى أحمد أحمد، ـ داليا عبد السلام سعد، ـ دعاء أحمد أبو بكر - لبنى عبد الرازق الخطيب

قسمى الفسيولوجيا الطبية والهستولوجيا و بيولوجيا الخلية ـ كلية الطب - جامعة عين شمس

خلقيه البحث: سن اليأس هو مرحلة فسيولوجيه في حياة السيدات مع تقدم العمر ،يصاحبه زيادة

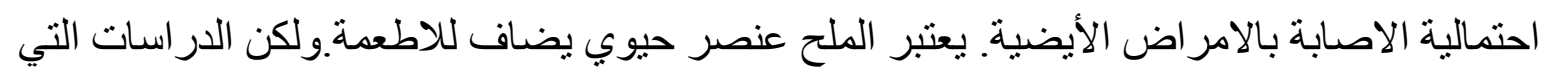
بعنوان التأثير ات الأيضية للتناول الزئير الئد للملح محدودة ومتناقضة.

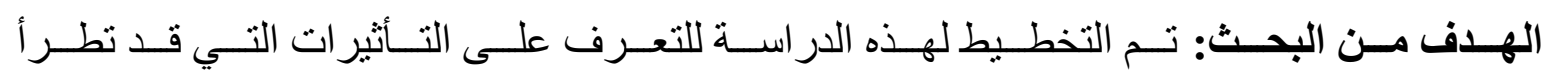

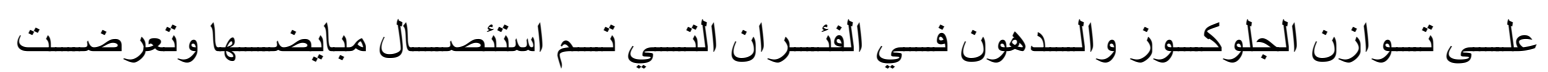
لتناول ز ائد اللمح في نموذج مشابه للسيدات فيما بعد انتهاء الطمث.

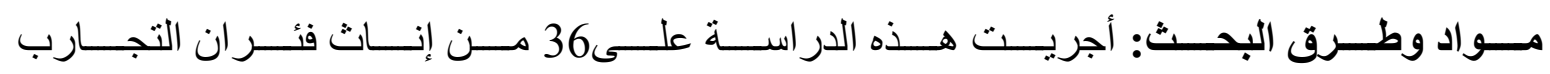

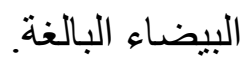

وقد تم تقسيم الفئران بشكل عشوائي إلى مجموعات متساويه وهم:

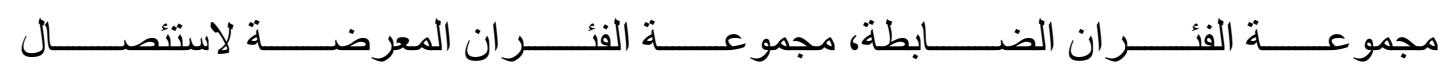

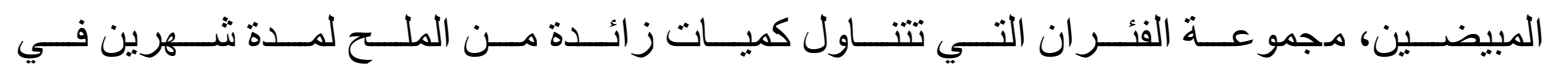
صورة 2\% ملح كلوريد صوديوم ومعرضة لاستئصسال المبيضين.

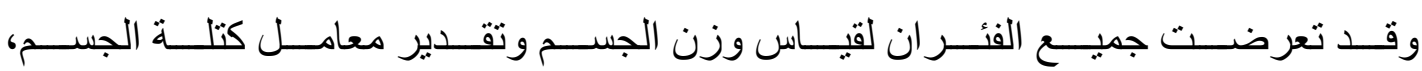

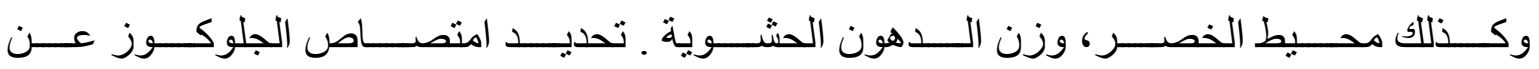

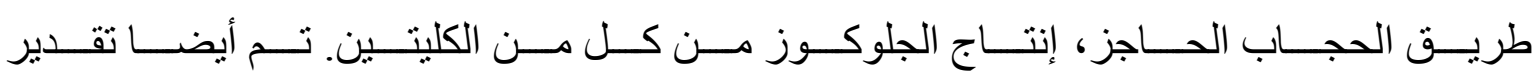

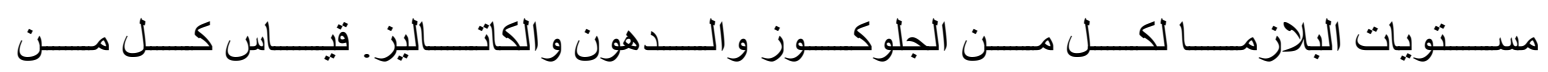

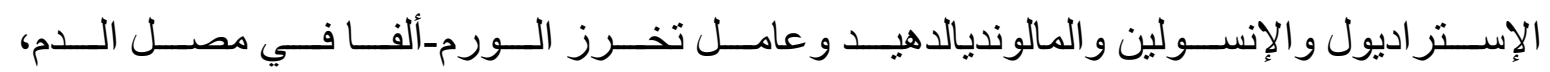

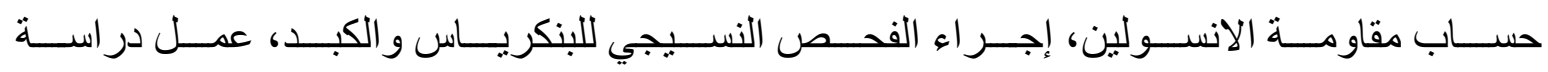
مناعية كيميائية لأنسجة البنكرياس لكاسبيز -3. 


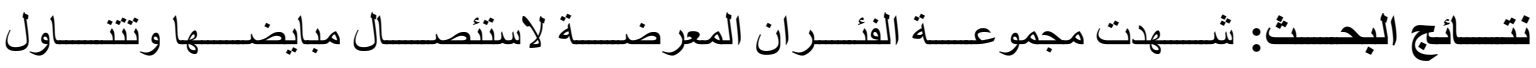

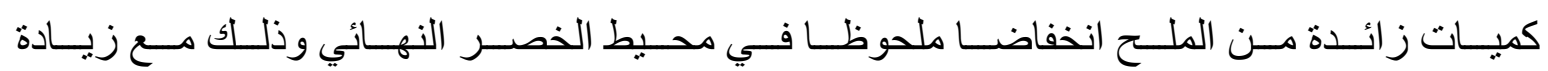

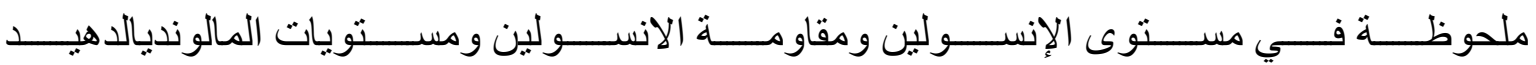

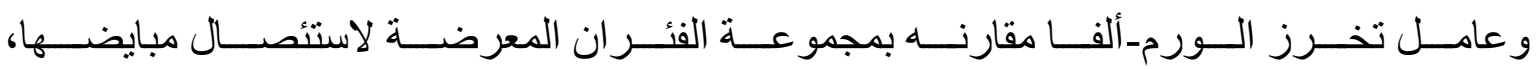

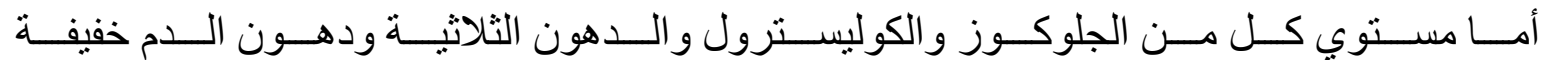

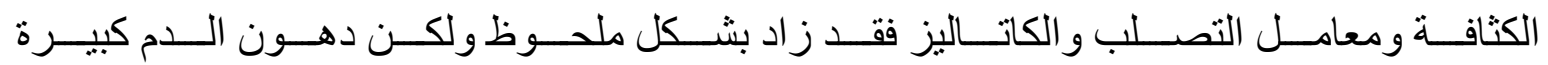

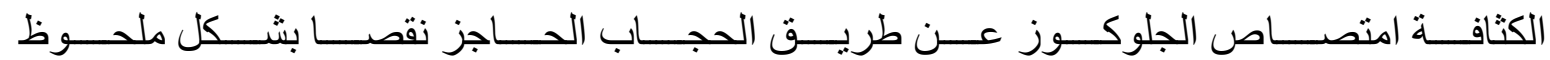
بالمقارنة مع مجمو عة الفئر ان الضـابطة.

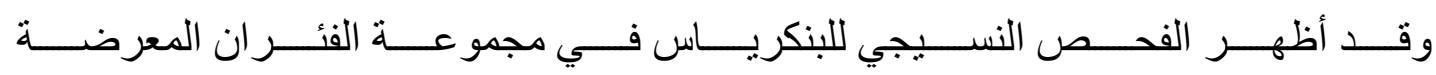

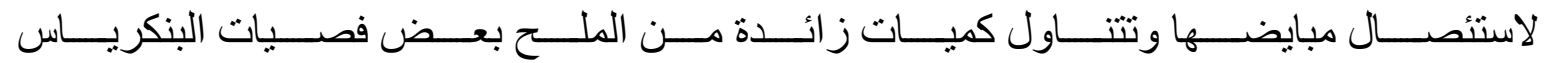

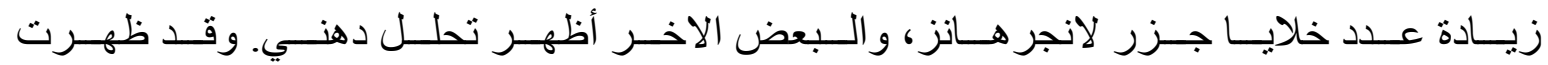

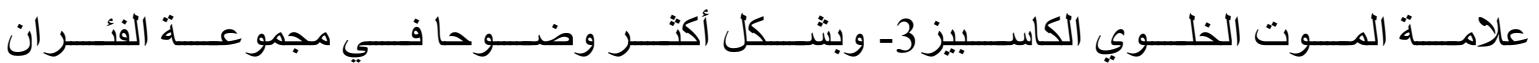

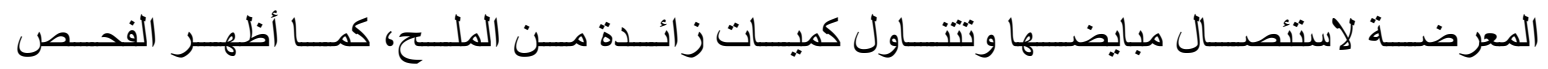

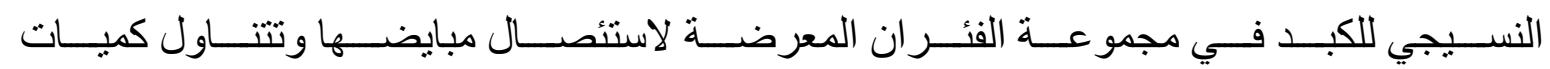

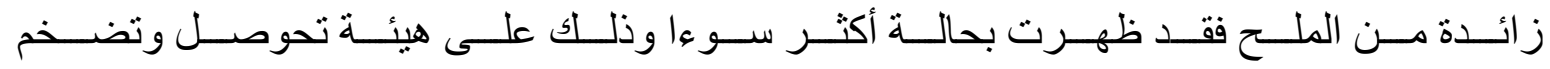

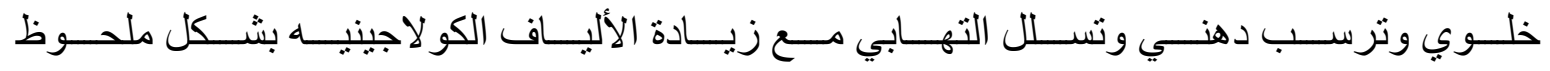
حول القناة البابية.

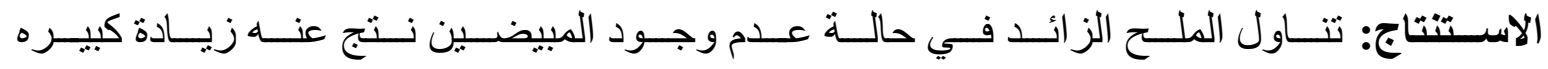

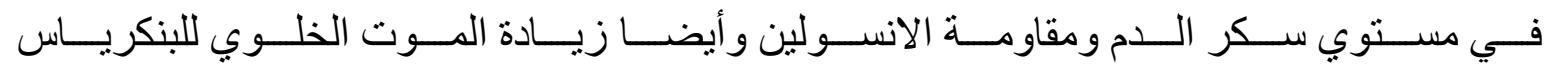

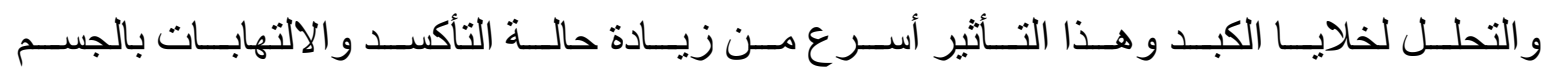
الناتجة عن زيادة تناول الملح. 